\title{
Duttonite, a new
}

quadrivalent vanadium oxide

from the Peanut mine,

Montrose County, Colorado

By M. E. Thompson, C. H. Roach, and Robert Meyrowitz

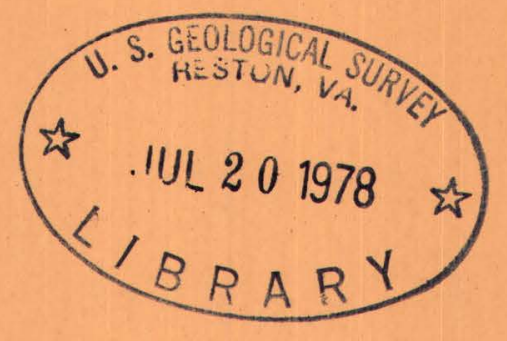

Trace Elements Investigations Report 582

UNITED STATES DEPARTMENT OF THE INTERIOR GEOLOGICAL SURVEY 
Geology and Mineralogy

This document consists of 13 pages.

Series A.

UNITED STATES DEPARTMENT OF THE INTERIOR

GEOLOGICAL SURVEY

DUTTONITE, A NEW QUADRIVATENT VANADIUM OXIDE FROM THE

PEANUT MINE, MONTROSE COUNTY, COLORADO*

By

M. E. Thompson, Carl H. Roach, and Robert Meyrowitz

March 1956

Trace Elements Investigations Report 582

This preliminary report is distributed without editorial and technical review for conformity with official standards and nomenclature. It is not for public inspection or quotation.

*This report concerns work done on behalf of the Division of Raw Materials of the U. S. Atomic Energy Commission. 
USCS - TEI -582

GEOLOGY AND MTHERALOGY

Distribution (Series A)

No. of copies

Atomic Energy Commission, Washington ....................

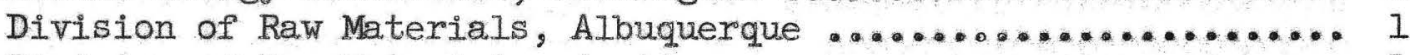

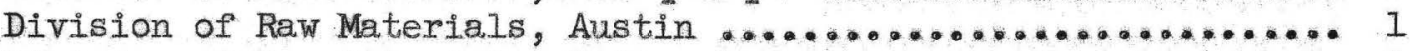

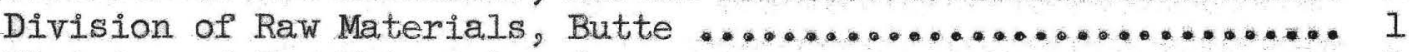

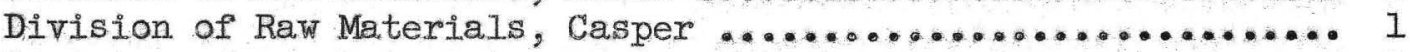

Division of Raw Materials, Denver .......................... 1

Division of Raw Materials, Ishpeming ...................... I

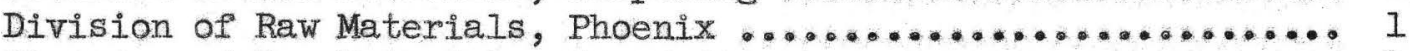

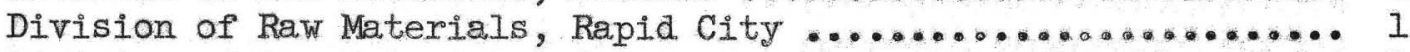

Division of Raw Materials, st. George ........................ I

Division of Raw Materials, Salt Iake City .................... I

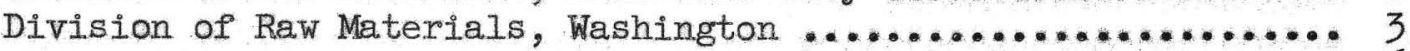

Exploration Division, Grand Junction Operations Office ........ 6

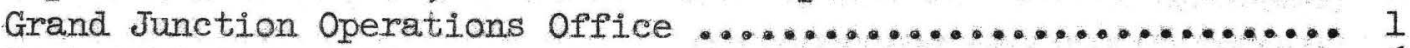

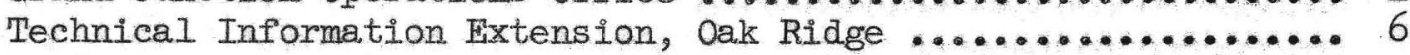

U. S. Geological Survey:

Fuels Branch, Washington ............................... I

Geochemistry and Petrology Branch, Washington ............... 25

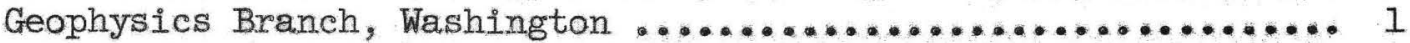

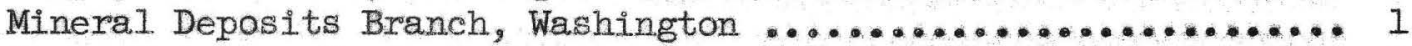

P. C. Bateman, Menlo Park ................................. I

A. I. Brokaw, Grand Junction ............................ 2

N. M. Denson, Denver .................................... 1

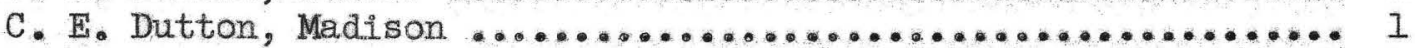

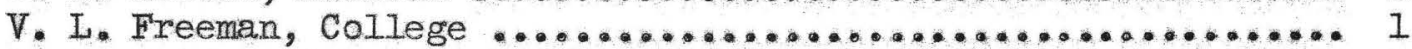

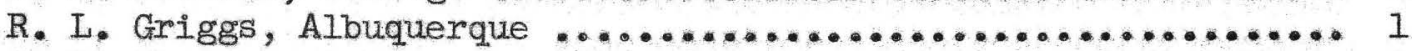

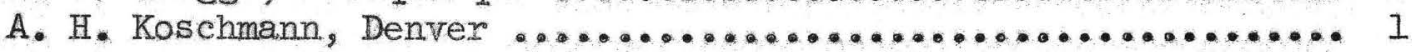

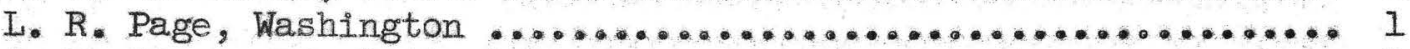

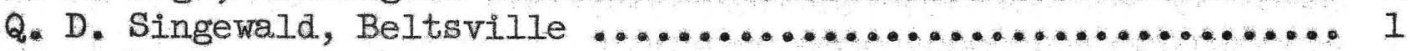

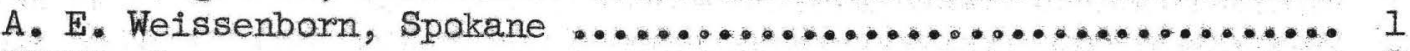

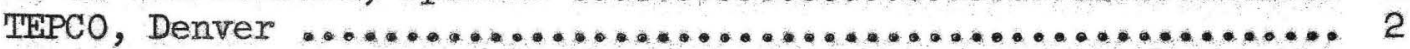

TEPCO, RPS, Washington, (including master) ................ 2 
CONTENTS

Page

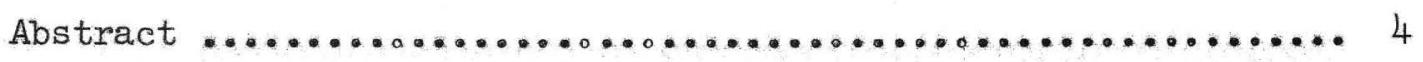

Introduction and acknowledgments $\ldots \ldots \ldots \ldots \ldots \ldots \ldots \ldots \ldots \ldots \ldots \ldots$

Occurrence ......................................... 5

Physical and optical properties ..................... 7

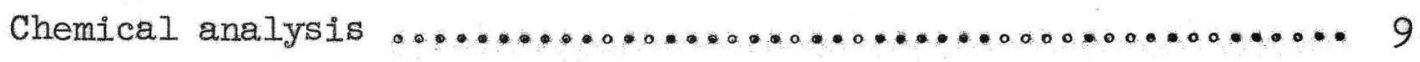

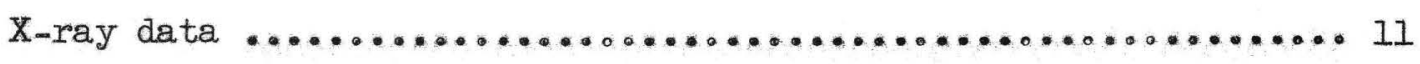

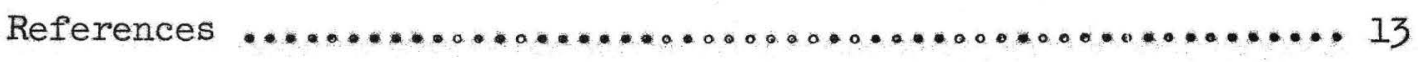

ILIUSTRATIONS

Page

Figure 1. Index map of the locality of duttonite, the Peanut

mine, Montrose County, Colorado .................. 6

2. Typical crystal habit of duttonite $\ldots \ldots \ldots \ldots \ldots \ldots \ldots . . . .8$

TABLES

Page

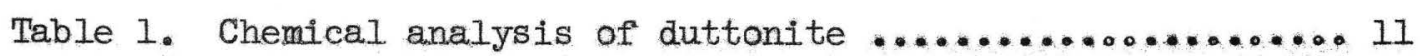

2. Powder diffraction data for duttonite $\ldots \ldots \ldots \ldots \ldots \ldots 12$ 
DUITONITE, A NEW QUADRIVAIENT VANADIUM OXIDE FROM THE PEANUT MINE, MONTROSE COUNTY, COLORADO

$\mathrm{By}$

M. E. Thompson, Carl H. Roach, and Robert Meyrowitz

\section{ABSTRACT}

Duttonite, a new quadrivalent vanadium oxide from the Peanut mine, Montrose County, Colo., has the formula Vo(OH)2. The mineral occurs as crusts and coatings of palembrown transparent platy crystals, as one of the first oxidation products of montroseite ore. It is associated with melanovanadite and abundant crystals of hexagonal native selenium. Duttonite is biaxial positive, $2 \mathrm{~V}$ is about $60^{\circ}$, dispersion is $\underline{\underline{r}}<\underline{\mathrm{V}}$, moderate; $\mathrm{X}=\underline{\mathrm{a}}$, pale pinkish brown; $\mathrm{Y}=\underline{c}$, pale yellow-brown; $\mathrm{Z}=\underline{\mathrm{b}}$, pale brown; $\alpha=1.810 \pm 0.003, \beta=1.900 \pm 0.003, \gamma>2.01$. The hardness is about 2.5 : the calculated specific gravity is 3.24 .

The chemical analysis shows, in percent: $\mathrm{V}_{2} \mathrm{O}_{3} 2.6, \mathrm{~V}_{2} \mathrm{O}_{4} 75.3, \mathrm{FeO} 0.4$, $\mathrm{H}_{2} \mathrm{O}$ 18.1, insoluble 4.2 , total 100.6 .

Duttonite is monoclinic, $\underline{a}_{0}=8.80 \pm 0.02 \mathrm{~A}, \underline{b}_{0}=3.95 \pm 0.01 \mathrm{~A}, \underline{c}_{0}=$ $5.96 \pm 0.02 \mathrm{~A}, \beta=90^{\circ} 40^{\prime} \pm 5^{\circ}$. The space group is $I 2 / \underline{c},\left(\underline{C}_{2 h}^{6}\right)$; the cell contents are $4\left[\mathrm{VO}(\mathrm{OH})_{2}\right]$. The erystals are strongly pseudo-orthorhombic, and the structure departs only slightly from the space group Imem.

Duttonite is named for Captain Clarence Edward Dutton (1841-1912). 


\section{INIRODUCIION AND ACKNOWLEDGMENTS}

A detailed study of the geology, geochemistry, and mineralogy of the vanadium-uranium ore at the Peanut mine, Montrose County, Colo., was begun early in 1954 by Carl H. Roach of the U. S. Geological Survey. A number of rare and new minerals were found in the ore and the study of these samples was undertaken by Mary E. Thompson. Duttonite is the first new vanadium mineral to be described from the Peanut mine. It is named for Captain Clarence Edward Dutton (1841-1912), who was one of the first geologists to work in the Colorado Plateau region and who was a member of the U. S. Geological Survey from 1879-91.

We are indebted to the following members of the Geological survey: K. E. Valentine for spectrographic analyses of duttonite, and M. E. Mrose and H. T. Evans, Jr., for measurement of the unit cell constants. This work is part of a program being conducted by the U. S. Geological Survey on behalf of the Division of Raw Materials of the U. S. Atomic Energy Commission.

\section{OCCURRENCE}

Duttonite has been found only at the Peanut mine, in the Bull Canyon mining district, Montrose County, Colo. The Peanut mine is about 15 miles west of Naturita, Colo., (fig. 1).

The Peanut mine is located along the axis of the Dry Creek Basin syncline, which lies between the Paradox Valley and Gypsum Valley salt anticlines (Cater, 1954).

The vanadium-uranium ore at the Peanut mine occurs in the upper orebearing sandstone of the Salt Wash sandstone member of the Morrison formation of Late Jurassic age. Ore bodies occur along the flanks of a buried channel 


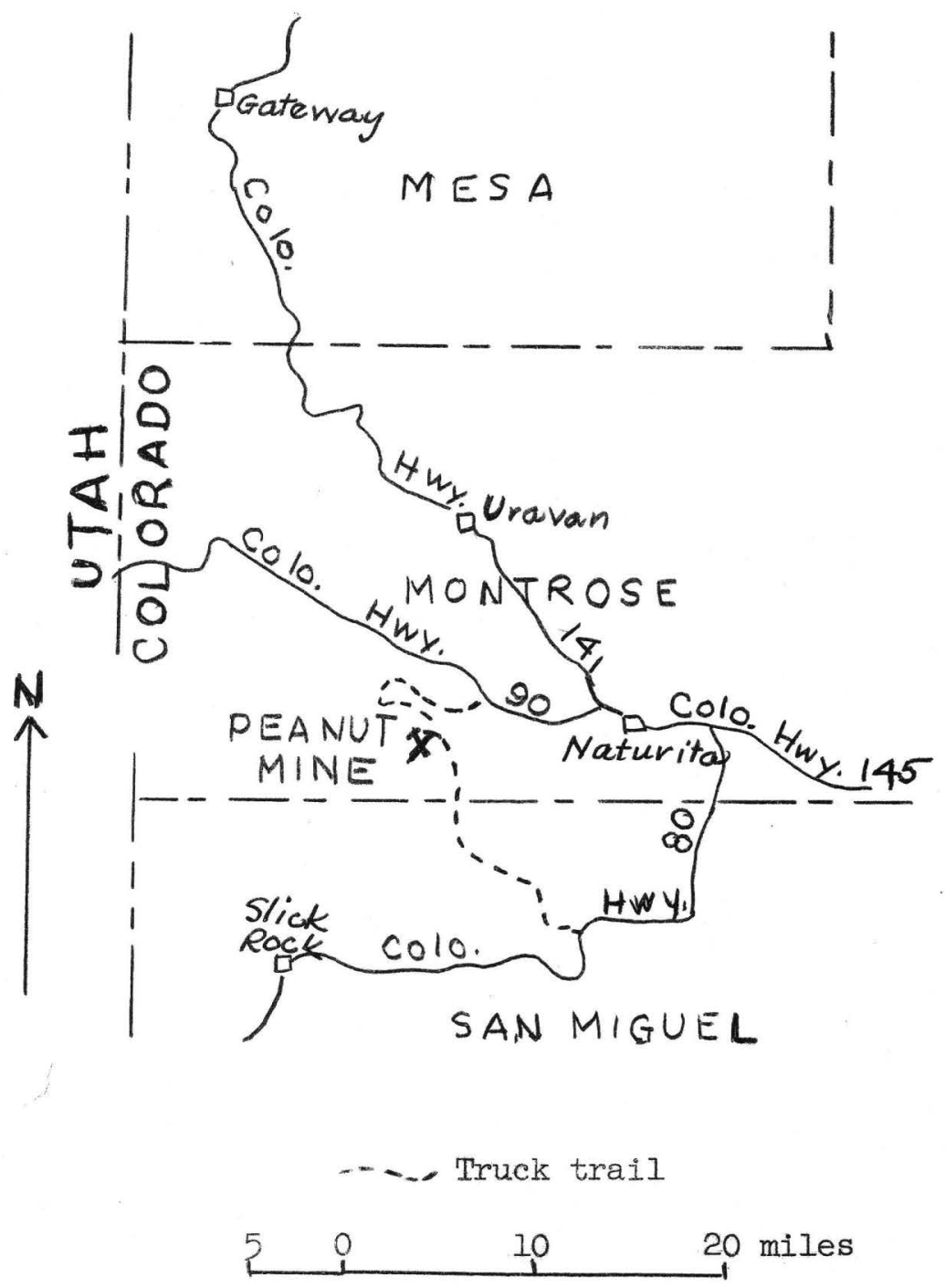

Figure 1.--Index map of the locality of duttonite, the Peanut mine, Montrose County, Colorado. 
and are localized by crossmbedding structures associated with the channel. The cross-bedding structures are called festoon cross lamination (Knight, 1930). The major festoon surfaces are relatively impermeable, and some have caused the formation of perched water tables. Most of the ore bodies are saturated. with water which has prevented much oxidation of the ore minerals although the regional water table is several hundred feet below the ore horizon. The principal ore minerals are montroseite, paramontroseite (Evans and Mrose, 1955), vanadiferous silicates, uraninite, and coffinite. The primary ore minerals impregnate sandstone and replace coalified wood. Along fractures in the ore-bearing sandstone there is commonly a thin massive coating of an undescribed vanadium oxide which partially recements the fractures.

On this coating duttonite occurs as crusts of randomly oriented sixsided platy crystals which range in size from extremely minute to about $0.5 \mathrm{~mm}$ on the longest dimension. Associated minerals are melanovanadite, abundant crystals of native selenium (Thompson, Roach, and Braddock, in press), and other undescribed vanadium minerals.

\section{PHYSICAL AND OPTICAL PROPERTIES}

Duttonite occurs as six-sided platy monoclinic crystals. The morphological elements (from X-ray measurements) are as follows:

$$
\begin{aligned}
& \text { Crystal class: monoclinic prismatic, } 2 / \mathrm{m} \\
& \text { a:b:e }=2.228: 1: 1.509, \beta=90^{\circ} 40^{\circ} \\
& \underline{p}_{0}^{8}=0.677, q_{0}{ }^{8}=1.509, \underline{x}_{0}^{8}=0.012 \\
& \text { Forms: } e\{001\}, a\{100\}, \underline{m}\{110\}
\end{aligned}
$$

The crystals are flattened parallel to $c\{001\}$, and are strongly pseudoorthorhombic in aspect ( $f$ ig, 2). In fact, the only positive evidence for the monoclinic symmetry is provided by the X-ray powder data. (See page 9.) 


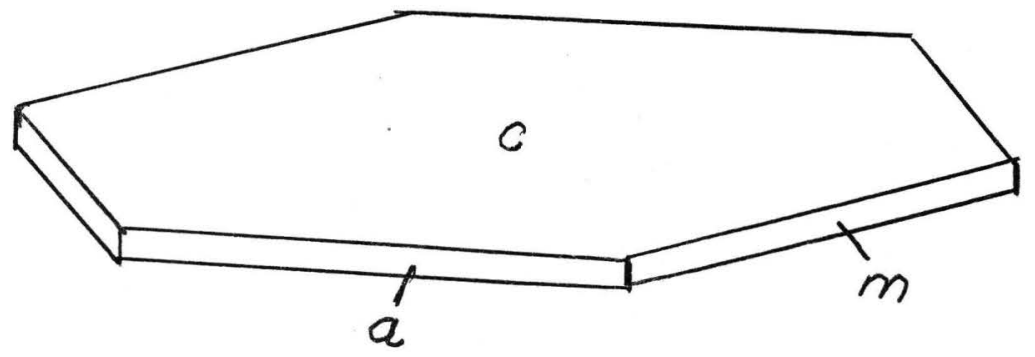

Figure 2.--Typical crystal habit of duttonite. 
A pronounced cleavage is present parallel to (100). The hardness is about 2.5. The specific gravity was not measured directly, but the mineral sinks in bromoform of specific gravity 2.9 and floats on methylene iodide of specific gravity 3.3. The specific gravity calculated from the X-ray data is 3.24 .

The optical properties of duttonite are consistent with the pseudoorthorhombic symmetry. It is biaxial positive, $2 \mathrm{~V}$ about $60^{\circ}$, dispersion $\underline{r}<\underline{\mathrm{V}}$, moderate. The indices of refraction, pleochroism, and optical orientation are summarized as follows:

$\begin{array}{cll}\text { Orientation } & \underline{\mathrm{n}} & \text { Pleochroism } \\ \mathrm{X}=\underline{\mathrm{a}} & \alpha=1.810 \pm 0.003 & \text { pale pinkish brown } \\ \mathrm{Y}=\underline{\mathrm{c}} & \beta=1.900 \pm 0.003 & \text { pale yellow-brown } \\ \mathrm{Z}=\underline{\mathrm{b}} & \gamma>2.01 & \text { pale brown }\end{array}$

CHEMICAL ANALYSIS

Duttonite occurs as aggregates of tiny platy crystals, altering from another undescribed vanadium oxide and intermixed with tiny crystals of hexagonal native selenium. The sample used for chemical analysis was prepared by hand-picking a number of aggregates of crystals and crushing each aggregate between glass slides. The crushed material was examined with a binocular microscope. The other vanadium oxide appeared as formless opaque blobs; the tiny acicular selenium crystals were not easily seen. Only the purest of the aggregates were saved, and by this means about $25 \mathrm{mg}$ was accumulated for the analysis.

A microqualitative spectrographic analysis by $K$. E. Valentine showed over 10 percent $\mathrm{V}, 0.1$ to 0.5 percent $\mathrm{Fe}$, and 0.05 to 0.1 percent $\mathrm{Si}, \mathrm{Al}$, and 
Ca. The blue green color of a solution of the mineral in concentrated HCI and the structure determination by Evans and Mrose indicate that the mineral is an oxide of $\mathrm{V}^{4+}$.

The selection of the procedures used for the chemical analysis was based upon the qualitative spectrographic analysis. $\mathrm{V}_{2} \mathrm{O}_{3}$ and $\mathrm{V}_{2} \mathrm{O}_{4}$ were calculated using the values obtained for the following determinations: (1) total reducing ability of the mineral, (2) total vanadium, and (3) Feo. The total reducing ability was determined by decomposing the mineral in boiling $(1+3)$ sulfuric acid and titrating with approximately 0.03 N standard potassium permanganate. The FeO content was determined spectrophotometrically by the o-phenanthroline procedure and calculated as Fe0. A 5-cm absorption cell was used. The total vanadium was determined spectrophotometrically by the hydrogen peroxide procedure using a separate sample which was dissolved by boiling with $(1+1)$ nitric acid. Orthophosphoric acid was used to mask the iron.

The insoluble material was determined by boiling the sample with $(1+3)$ sulfuric acid in a weighed Schwarz-Bergkampf microfilter beaker. The residue was filtered and washed with water and dried to constant weight at $110^{\circ} \pm 5^{\circ} \mathrm{C}$. These weighings were made with a microbalance. An X-ray powder pattern of the insoluble material by George Ashby of the U. S. Geological Survey showed it to consist of hexagonal selenium and quartz.

Water was determined by use of a modified microcombustion train of the type used for the determination of carbon and hydrogen in organic compounds. The sample was decomposed by ignition at $900^{\circ} \mathrm{C}$ in a stream of oxygen. The results of the chemical analysis are shown in table 1 . The percentages, when recalculated to 100 percent after eliminating the insoluble fraction, agree well with the theoretical values for $\mathrm{V}_{2} \mathrm{O}_{4} \cdot 2 \mathrm{H}_{2} \mathrm{O}$. This result is 
Table I. -Chemical analysis of duttonite, in percent. (Robert Meyrowitz, analyst)

\begin{tabular}{lccc}
\hline & $\begin{array}{c}\text { Analysis of } \\
\text { duttonite }\end{array}$ & $\begin{array}{c}\text { Analysis, less insoluble, } \\
\text { recalculated to } 100 \text { percent }\end{array}$ & $\mathrm{VO}(\mathrm{OH})_{2}$ \\
\hline $\mathrm{V}_{2} \mathrm{O}_{3}$ & 2.6 & 2.7 & 82.2 \\
$\mathrm{~V}_{2} \mathrm{O}_{4}$ & 75.3 & 78.1 & 17.8 \\
$\mathrm{FeO}$ & 0.4 & 0.4 & \\
$\mathrm{H}_{2} \mathrm{O}$ & 18.1 & 18.8 & 100.0 \\
Insoluble & 4.2 & & 100.0
\end{tabular}

in agreement with the composition which has been predicted for duttonite by Evans and Mrose on the basis of a crystal structure study now in preparation.

\section{X-RAY DATA}

An X-ray diffraction powder pattern of duttonite was taken with a Debye-Scherrer camera (114.6-mm diameter) using CuKo radiation. The measured powder data are listed in table 2. M. E. Mrose has determined the unit cell of duttonite by the Buerger precession method as follows: $a_{0}=8.80 \pm 0.02 \mathrm{~A}$, $\underline{b_{0}}=3.95 \pm 0.01 \mathrm{~A}, \underline{c}_{0}=5.96 \pm 0.02 \mathrm{~A}, \mathrm{~B}=90^{\circ} \pm 1 ;$ space group $\underline{I 2} / \underline{\mathrm{c}}\left(\underline{\mathrm{C}}_{2 \mathrm{~h}}\right)$; unit cell contents, $4\left[\mathrm{VO}(\mathrm{OH})_{2}\right]$. Because of the poor quality of the crystals, the monoclinic angle could not be detected in the single crystal study, and the pseudo-orthorhombic space group Imcm was at first assigned to the mineral. H. T. Evans has shown, however, that the orthorhombic lattice accounts for the powder spacings only approximately, and that a good fit of calculated 
and observed spacings can be obtained only by assuming monoclinie symetry with $\beta=90^{\circ} 40^{\circ} \pm 5$. His interpretation of the powder pattern is shown in table 2. The crystal structure study of duttonite carried out by Evans and Mrose will be published at a later date.

Table 2.--Powder diffraction data for duttonite, CuKo radiation, 114.6-mm diamter camera. d (calculated) listed for monoclinic unit cell: $\underline{\mathrm{a}}_{0}=8.80 \mathrm{~A}, \underline{\mathrm{b}}_{0}=3.95 \mathrm{~A}, \underline{\mathrm{c}}_{0}=5.96 \mathrm{~A}, \beta=90^{\circ} 40 \%$ space group $\underline{\mathrm{I}} 2 / \underline{\mathrm{c}}$.

\begin{tabular}{|c|c|c|c|c|c|c|c|}
\hline$h k$. & $\underline{\mathrm{d}}$ (calc.) & $\underline{d}\left(\mathrm{obs}_{.}\right)$ & $I$ & $h k I$ & $\underline{d}($ calc. $)$ & $\underline{a}$ (obs.) & I \\
\hline 200 & 4.401 & 4.402 & 100 & 004 & 1.491 & 1.491 & 4 \\
\hline 110 & 3.604 & 3.609 & 85 & 420 & 1.470 & & \\
\hline 011 & 3.293 & 3.290 & 13 & 600 & 1.467 & 1.468 & 6 \\
\hline 002 & 2.982 & 2.981 & 6 & 512 & 1.422 & 1.423 & 2 \\
\hline 2ేII & 2.645 & 2.637 & 13 & 20 04 & 1.417 & & \\
\hline 211 & 2.629 & & & 512 & 1.409 & & \\
\hline 2̄o2 & 2.482 & 2.480 & 15 & 204 & 1.407 & 1.407 & 2 \\
\hline 202 & 2.455 & 2.454 & 15 & 413 & 1.389 & & \\
\hline 310 & 2.361 & & & 114 & 1.380 & 1.380 & 3 \\
\hline III & 2.303 & & & 114 & 1.375 & & \\
\hline 112 & 2.292 & & & 413 & 1.375 & & \\
\hline 400 & 2.201 & 2.202 & 7 & 611 & 1.343 & & \\
\hline$\underline{020}$ & 1.975 & 1.974 & 14 & 611 & 1.337 & & \\
\hline 312 & 1.857 & 1.860 & 5 & 602 & 1.322 & & \\
\hline 312 & 1.840 & & & 422 & 1.322 & 1.324 & 3 \\
\hline 121 & 1.835 & & & 422 & 1.314 & 1.314 & 2 \\
\hline 411 & 1.835 & 1.838 & 21 & 602 & 1.310 & 1.309 & 1 \\
\hline 121 & 1.832 & & & 130 & 1.302 & & \\
\hline 411 & 1.824 & & & 031 & 1.286 & 1.285 & 3 \\
\hline 220 & 1.802 & 1.801 & 3 & 521 & 1.286 & & \\
\hline 402 & 1.780 & 1.779 & 7 & 521 & 1.281 & & \\
\hline 013 & 1.776 & & & 314 & 1.265 & & \\
\hline 402 & 1.761 & 1.759 & 6 & 314 & 1.254 & 1.258 & 1 \\
\hline 213 & 1.653 & 1.656 & 2 & 404 & 1.237 & & \\
\hline 022 & 1.647 & & & 231 & 1.235 & 1.235 & 3 \\
\hline 213 & 1.641 & 1.639 & 2 & 231 & 1.233 & & \\
\hline 510 & 1.610 & 1.611 & 3 & 404 & 1.228 & 1.229 & 1 \\
\hline 321 & 1.578 & 1.580 & 6 & 710 & 1.199 & 1.199 & 3 \\
\hline 321 & 1.573 & & & 132 & 1.194 & & \\
\hline टె22 & 1.545 & 1.542 & 3 & 132 & 1.193 & & \\
\hline 222 & 1.539 & & & 620 & 1.178 & 1.179 & 2 \\
\hline
\end{tabular}




\section{REFERENCES}

Cater, F.W., 1954, Geology and map of the Bull Canyon quadrangle:

U. S. Geol. Survey, Geol. Quad. Map Series GQ 33.

Evans, H. T., Jr., and Mrose, M. E., 1955, A crystal chemical study of montroseite and paramontroseite: Am. Mineralogist, v. 40, p. 861-875.

Knight, S. H., 1930, Festoon cross-lamination (abs.): Geol. Soc. America Bull., v. 41, p. 86.

Thompson, M. E., Roach, Carl, and Braddock, William, in press, New occurrences of native selenium: Am. Mineralogist. 